\title{
Планарный электрооптический модулятор на основе теплостойких упорядоченных полимеров
}

\author{
С.Л. Микерин $^{1,2, *}$, [А.И. Плеханов $]^{1}$, А.Э. Симанчук ${ }^{1,2}$, А.В. Якиманский ${ }^{3}$, \\ В.В. Шелковников ${ }^{2}$, Н.А. Валишева ${ }^{4}$ \\ ${ }^{1}$ Институт автоматики и электрометрии СО РАН \\ ${ }^{2}$ Новосибирский институт органической химии им. Н.Н. Ворожчьова СО РАН \\ ${ }^{3}$ Институт высокомолекулярных соединений РАН \\ ${ }^{4}$ Институт физики полупроводников им. А.В. Ржанова СО РАН \\ *E-mail: mikerinsl@iae.sbras.ru
}

DOI:10.31868/RFL2018.185-186

Рост объемов передачи информации по оптоволоконным линиям связи привел к необходимости развивать скоростные устройства модуляции несущего излучения. Одними из наиболее перспективных сред для ЭО модуляторов являются хромофорсодержащие полимеры, упорядоченные на стадии изготовления. Такие среды демонстрируют квадратичную оптическую нелинейность на один-два порядка выше, чем неорганические кристаллические среды $[1,2]$, и позволяют лучше согласовать оптическую и СВЧ волны, что особенно важно для расширения рабочей полосы. Дополнительным преимуществом таких сред является их композитность, позволяющая осуществлять направленный поиск компонентов с целью получить необходимые свойства. Нелинейно-оптический компонент в таких материалах представляет собой хромофор - органический комплекс с большой резонансной гиперполяризуемостью [1]. Полимерная матрица играет роль фиксирующего остова и определяет основные оптические, физико-химические, электрические свойства и, что очень важно, термическую стабильность результирующей композиции. Синтез оригинальных хромофоров в первую очередь решает проблему доступности полимерных ЭО материалов для широкого применения. Использование термо- и теплостойких полимеров открывает новые возможности для ЭО материалов с высокой температурной и временной устойчивостью нелинейного отклика. В данной работе представлены результаты разработки и реализации технологии изготовления планарных ЭО модуляторов на основе синтезированных оригинальных теплостойких полиимидов, а также результаты применения оригинальных синтезированных оптически активных хромофоров.

В настоящей работе использовался один из этого ряда оригинальных полиимидов с высокой температурой стеклования, исследованных нами ранее [36] - полиимид на основе 3,3'-дигидрокси-4,4'-диаминодифенилметана и 4,4'(фенилен-1,3-диокси)дифталевого ангидрида с ковалентным присоединением хромофора DR13. Оригинальный синтезированный пиразолиновый хромофор 5PIP-NET $^{1}$ [7] для применения в модуляторе смешивался в соотношении 5/95 масс. $\%$ с аморфным поликарбонатом (Aldrich Chemistry). Тонкие пленки на подложках различного типа получались методом центрифугирования (около 600 об/мин) из растворов полимерных композиций. Для получения ЭО отклика пленочные структуры подвергались полингу методом, описанным в [8].

Для создания полностью полимерной волноводной структуры был выбран УФ-отверждаемый полимер (стандартный фоторезист SU-8), который наносился на кремниевую подложку с общим электродом в два слоя: базовый (толщина 2

\footnotetext{
${ }^{1}$ 2-(5-оксо-3-циано-1-этил-4-(4-(3-фенил-5-(2,3,5,6-тетрафтор-4-(пиперидин-1-ил)фенил)-4,5дигидро-1Н-пиразол-1ил)-стирил)-1Н-пиррол-2(5Н)-илиден)-малононитрил
} 
мкм) и структурированный (1 мкм), обрабатываемый с помощью маски. В целом эти слои составляли нижнюю обкладку оптической волноводной структуры, в которой был сформирован массив разных вариантов волноводных каналов как фазовых модуляторов, так и амплитудных (интерферометр Маха-Цендера). ЭО полимер заполнял сформированные каналы, образуя световедущую жилу толщиной 1,5-2 мкм. Верхняя обкладка волноводной структуры (5 мкм) изготовлялась из коммерческого УФ-отверждаемого полимера NOA 61. Качество созданных структур оценивалось с помощью оптической и сканирующей электронной микроскопии. После отбраковки каналов на поверхности структуры над активными участками волноводов формировались управляющие электроды.

Модулирующие свойства волноводных структур изучались при частоте управляющего напряжения 1 кГц. Излучение одномодового лазера (длина волны 1,3 мкм) заводилось через торец волноводной структуры на сколотой подложке с помощью волокна с сохранением поляризации и концевой линзы. Выходное излучение регистрировалось фотодатчиком через объектив 20х.

Общие потери излучения на ввод-вывод и распространение в созданных модуляторах не превысили 19 дБ. Амплитудные модуляторы в созданном массиве на основе полиимида с DR13 демонстрировала полуволновое напряжение от 24 до $38 \mathrm{~B}$. Минимальное значение параметра $\mathrm{L} \cdot \mathrm{V}_{\pi}=31 \mathrm{~cm} \cdot \mathrm{B}$ при длине активной части $\mathrm{L}=1,3$ см. Фазовый модулятор на основе хромофора 5-PIPNET в поликарбонате показал сравнительно низкий параметр $L \cdot V_{\pi}=87 \mathrm{~cm} \cdot \mathrm{B}$. Это указывает на близость данного хромофора и DR13 по ЭО отклику, учитывая различие в концентрации хромофоров в поликарбонате и полиимиде. При этом ЭО отклик в полиимиде сохраняется при температурах до $120{ }^{\circ} \mathrm{C}$, а в поликарбонате - до $100{ }^{\circ} \mathrm{C}$.

Таким образом, синтезированы оригинальные хромофорсодержащие теплостойкие полиимиды и хромофор, разработаны технологические подходы, подобраны материалы для создания фазовых и амплитудных планарных модуляторов на их основе. Созданы компактные волноводные модуляторы, демонстрирующие параметр $\mathrm{L} \cdot \mathrm{V}_{\pi} 31 \mathrm{~cm} \cdot \mathrm{B}$ и низкие оптические потери.

Работа выполнена с использованием оборудования Центра коллективного пользования «Спектроскопия и оптика» (http://ckp-rf.ru/ckp/3046/) при финансовой поддержке РНФ (грант 16-13-10156).

\section{Литература}

[1] L.R. Dalton, W.H. Steier, B.H. Robinson et al, J. Mater. Chem. 9, 1905-1920 (1999)

[2] L.R. Dalton, P.A. Sullivan, and Bale D. H. Chem. Rev. 110, 25-55 (2010)

[3] G.I. Nosova, I.G. Abramov, N.A. Solovskaya et al, Polym. Sci. Ser. B3 53, 73 (2011)

[4] A.V. Yakimansky, G.I. Nosova, N.A. Solovskaya et al, Chem. Phys. Lett. 510, $237-241$ (2011)

[5] A.I. Gorkovenko, A.I. Plekhanov, A.E. Simanchuk et al, Optoelectronics, Instrumentation and Data Processing. 50, No. 1, 96-101 (2014) DOI: 10.3103/S8756699014010129.

[6] A.I. Gorkovenko, A.I. Plekhanov, A.E. Simanchuk et al, J. Appl. Phys. 116, 223104 (2014) DOI: $10.1063 / 1.4904194$

[7] К.Д. Ерин, И.Ю. Каргаполова, Н.А. Орлова и др. Сборник тезисов докладов (Ш:У-9): Объединённая международная конферениия по органической химии «Байкальские чтения2017» (Иркутск, 27 августа - 2 сентября), 129 (2017).

[8] S.N. Atutov, S.L. Mikerin, A.I. Plekhanov et al, Optoelectronics, Instrumentation and Data Processing. 54, No. 1, 39-45 (2018) DOI: 10.3103/S8756699018010077 